Atmos. Chem. Phys., 13, 11609-11623, 2013

www.atmos-chem-phys.net/13/11609/2013/

doi:10.5194/acp-13-11609-2013

(c) Author(s) 2013. CC Attribution 3.0 License.

\title{
Stable atmospheric methane in the 2000s: key-role of emissions from natural wetlands
}

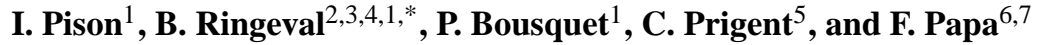 \\ ${ }^{1}$ Laboratoire des Sciences du Climat et de l'Environnement, Institut Pierre-Simon Laplace, CEA/CNRS/UVSQ, UMR8212, \\ Gif-sur-Yvette, France \\ ${ }^{2}$ Institute of Marine and Atmospheric Research Utrecht (IMAU), Utrecht University, Utrecht, the Netherlands \\ ${ }^{3}$ SRON Netherlands Institute for Space Research, Utrecht, the Netherlands \\ ${ }^{4}$ Department of Systems Ecology, Vrije Universiteit, Amsterdam, the Netherlands \\ ${ }^{5}$ Laboratoire d'Études du Rayonnement et de la Matière en Astrophysique, Observatoire de Paris, CNRS, Paris, France \\ ${ }^{6}$ Laboratoire d'Études en Géophysique et Océanographie Spatiales, Institut de Recherche pour le Développement, Toulouse, \\ France \\ ${ }^{7}$ Indo-French Cell for Water Sciences, IRD-IISc Joint International Laboratory, Indian Institute of Science, Bangalore, India \\ *now at: INRA, UMR1220 TCEM, 33883 Villenave d'Ornon, France
}

Correspondence to: I. Pison (isabelle.pison@lsce.ipsl.fr)

Received: 1 February 2013 - Published in Atmos. Chem. Phys. Discuss.: 4 April 2013

Revised: 14 October 2013 - Accepted: 29 October 2013 - Published: 2 December 2013

\begin{abstract}
Two atmospheric inversions (one fine-resolved and one process-discriminating) and a process-based model for land surface exchanges are brought together to analyse the variations of methane emissions from 1990 to 2009. A focus is put on the role of natural wetlands and on the years 2000-2006, a period of stable atmospheric concentrations.

From 1990 to 2000, the top-down and bottom-up visions agree on the time-phasing of global total and wetland emission anomalies. The process-discriminating inversion indicates that wetlands dominate the time-variability of methane emissions ( $90 \%$ of the total variability). The contribution of tropical wetlands to the anomalies is found to be large, especially during the post-Pinatubo years (global negative anomalies with minima between -41 and $-19 \mathrm{Tg} \mathrm{yr}^{-1}$ in 1992) and during the alternate 1997-1998 El-Niño/19981999 La-Niña (maximal anomalies in tropical regions between +16 and $+22 \mathrm{Tg} \mathrm{yr}^{-1}$ for the inversions and anomalies due to tropical wetlands between +12 and $+17 \mathrm{Tg} \mathrm{yr}^{-1}$ for the process-based model).

Between 2000 and 2006, during the stagnation of methane concentrations in the atmosphere, the top-down and bottom-up approaches agree on the fact that South America is the main region contributing to anomalies in natural wetland emissions, but they disagree on the sign
\end{abstract}

and magnitude of the flux trend in the Amazon basin. A negative trend $\left(-3.9 \pm 1.3 \mathrm{Tg} \mathrm{gr}^{-1}\right)$ is inferred by the process-discriminating inversion whereas a positive trend $\left(+1.3 \pm 0.3 \mathrm{Tg} \mathrm{yr}^{-1}\right)$ is found by the process model. Although processed-based models have their own caveats and may not take into account all processes, the positive trend found by the B-U approach is considered more likely because it is a robust feature of the process-based model, consistent with analysed precipitations and the satellite-derived extent of inundated areas. On the contrary, the surface-data based inversions lack constraints for South America. This result suggests the need for a re-interpretation of the large increase found in anthropogenic methane inventories after 2000.

\section{Introduction}

The growth rate of atmospheric methane $\left(\mathrm{CH}_{4}\right)$ has experienced large variations since the early 1990s: after a decade of decrease, interrupted by a peak in 1997-1998 (Dlugokencky et al., 1998; Cunnold et al., 2002; Wang et al., 2004; Bousquet et al., 2006), the growth rate of atmospheric methane remained small from 1999 to 2006, except a peak in 20022003, only to increase again since 2007 (Rigby et al., 2008;

Published by Copernicus Publications on behalf of the European Geosciences Union. 
Dlugokencky et al., 2009; Bousquet et al., 2011). As methane is emitted by a large variety of sources, the explanations for the observed atmospheric variations have generally implied changes in several source or sink types.

The sources involved in the variations of the 1990s are now well understood, although their relative magnitude may still be debated.

The 1991-93 growth rate anomaly is linked to the Pinatubo eruption, which led to a decrease in methane loss, due to reduced tropospheric hydroxyl radical $(\mathrm{OH})$ concentrations and stratospheric chemistry changes (Bândă et al., 2013), followed by a decrease in natural wetland emissions. The negative impact of this volcanic event on wetland $\mathrm{CH}_{4}$ emissions is due to its effects on the climate, with both cooling (Dlugokencky et al., 1996) and precipitation anomalies in the Northern Hemisphere (Walter et al., 2001b; Dlugokencky et al., 2011), likely slightly amplified by sulphur deposition (Gauci et al., 2008). The collapse of the economy of the former USSR and Eastern Europe has also led to decreased anthropogenic emissions starting in 1991 and spanning most of the 1990s (Dlugokencky et al., 2003).

The 1997-99 large growth rate anomaly is explained by a positive anomaly in emissions from biomass burning, both in the Tropics and at high latitudes (van der Werf et al., 2006; Langenfelds et al., 2002), together with a negative anomaly in emissions from tropical wetlands in 97-98, linked to dry El-Niño conditions, followed by a positive anomaly in the same emissions in 98-99, linked to wet La-Niña conditions (Bousquet et al., 2006; Chen and Prinn, 2006).

Overall, the role of wetlands in changes in atmospheric methane has often been identified as dominant (Chen and Prinn, 2006; Bousquet et al., 2006, 2011; Kirschke et al., 2013), linked to meteorological conditions of temperatures and precipitations (Dlugokencky et al., 2009; Bousquet et al., 2011). These conditions are thought to lead to both changes in the wetland extent (e.g. Ringeval et al., 2010) and the $\mathrm{CH}_{4}$ flux per wetland area (e.g.Bloom et al., 2010). The impact of wetland emissions is often thought to be combined with changes in $\mathrm{OH}$ concentrations (Wang et al., 2004; Monteil et al., 2011), although it is now well accepted that interannual changes in $\mathrm{OH}$ concentrations are limited to $1-3 \%$ and can therefore explain only a limited part of the observed changes in the methane growth rate (Montzka et al., 2011).

The analysis of the variations of atmospheric methane after 1999 is still largely debated.

Various scenarios have been suggested to explain the stabilization of methane concentrations between 2000 and 2006: (i) reduced global fossil-fuel-related emissions, estimated from AGAGE and NOAA (Chen and Prinn, 2006) or from ethane emissions used as a proxy to fossil-fuel-related $\mathrm{CH}_{4}$ emissions (Aydin et al., 2011; Simpson et al., 2012); (ii) compensation between increasing anthropogenic emissions (as inferred by inventories such as EDGAR4, EDGAR 4, 2009) and decreasing wetland emissions (Bousquet et al., 2006); (iii) a decrease in emissions due to rice-paddies, attributed to changes in agricultural practices (Kai et al., 2011); (iv) stable microbial and fossil-fuel-related emissions in the early $2000 \mathrm{~s}$ (Levin et al., 2012) and/or (v) significant (Rigby et al., 2008) to small (Montzka et al., 2011) changes in $\mathrm{OH}$ concentrations. A recent synthesis (Kirschke et al., 2013) suggests that a scenario with stable to increasing microbial emissions and stable to decreasing fossil fuel emissions is more likely than others but do not attribute changes regionally. For a proper closure of the methane budget and the development of realistic future climate scenarios, methane emissions during this stabilization period should be understood and precisely quantified.

The increase of methane concentrations observed since 2007 (Rigby et al., 2008; Dlugokencky et al., 2009; Sussmann et al., 2012) is also still not understood with hints to possible increasing anthropogenic emissions (EDGAR 4, 2009) and increasing wetland emissions in relation to abnormal precipitations over tropical lands in the late 2000s (Bousquet et al., 2011; Dlugokencky et al., 2009). However the relative magnitude of changes in anthropogenic emissions and wetland emissions is still uncertain (Kirschke et al., 2013).

Methane emissions can be investigated using processbased models and inventories (bottom-up or B-U approach), and atmospheric inversions (top-down or T-D approach). Atmospheric inversions combine atmospheric observations of $\mathrm{CH}_{4}$, an atmospheric chemistry and transport model, and prior information about sources and sinks. The flux estimates that give the best fit to the observed atmospheric concentrations are derived by optimisation. However, atmospheric inversions provide a limited insight into the underlying biogeochemical processes controlling emissions, particularly over regions where several processes and sources overlap. B-U models computing wetland (Melton et al., 2013) or biomassburning (van der Werf et al., 2010) methane emissions incorporate knowledge of small-scale processes but they need additional information and constraints to project their local emission estimates to larger scales compatible with the atmospheric signals. B-U emission inventories (EDGAR 4, 2009; EPA, 2011) are based on country-scale energy use and agricultural statistics and usually provide yearly to decadal estimates of anthropogenic emissions at global and national scales. B-U and T-D approaches bring complementary information. It is therefore powerful to confront them: when agreement is found between these two approaches, statements are stronger; when disagreement is found, regions and/or processes which need more attention are more clearly identified.

In this study, our aim is to bring new elements to understand methane emissions between 1990 and 2009, with a focus on the stabilization period (2000-2006). Following the global analysis of Kirschke et al. (2013), we propose here an analysis based on two inversion systems (T-D) and one landsurface model of wetland emissions (B-U). Our aim is to progress in the identification of the processes and the regions 
which drive methane emission anomalies and particularly, which explain the stabilization period for concentrations.

For this, we analyse in the following: (i) the total global to regional methane emissions, as inferred by two different atmospheric inversions (T-D); (ii) the wetland emissions, as inferred by one inversion (the one which is able to discriminate the various sources or sinks) and by one process-based model of vegetation (B-U). The methodology of the processbased model and the two inversions is described in Sect. 2; results are given in Sect. 3 at the global (Sect. 3.1) and regional (Sect. 3.2) scales.

\section{Methodology}

We combine the results of a process-based model for natural wetland emissions, ORCHIDEE (Krinner et al., 2005; Ringeval et al., 2010, 2011), together with the $\mathrm{CH}_{4}$ fluxes estimated by two different atmospheric inversions, variational (Chevallier et al., 2005; Pison et al., 2009) and analytical (Bousquet et al., 2005). Note that the B-U and T-D methods to be compared were not chosen considering their a priori potential agreement but their independence (e.g. the B-U emissions are not used as prior in the inversions, the meteorological forcings are not the same).

\subsection{Process model for natural wetland emissions}

The model of $\mathrm{CH}_{4}$ emissions by natural wetlands used here (hereafter ORCHIDEE) is based on the ORCHIDEE global vegetation model (Krinner et al., 2005) which simulates land energy budget, hydrology, and carbon cycling. It was chosen for this study because:

- it makes it possible to vary important parameters (inundated area with satellite or computed, see below)

- it is not used in the two inversions as a prior

- it has been compared to other models (in WETCHIMP, see details below).

ORCHIDEE has then been developed (Ringeval et al., 2010, 2011) to simulate:

- The $\mathrm{CH}_{4}$-emitting wetland area dynamic, using some TOPMODEL concepts (Ringeval et al., 2012). The wetland extents are here normalized to match Papa et al. (2010). A global, multi-year dataset giving the monthly distribution of flooded areas at $\mathrm{a} \approx 25 \mathrm{~km}$ resolution has been generated. It is based on multiple satellite observations which are specifically sensitive to surface water (Papa et al., 2010; Prigent et al., 2012). It is built using a combination of satellite data including passive microwave observations and a linear mixture model to account for vegetation. Three wetland classes, differing by the value of the water table depth, are simulated for each grid cell and at each time step: saturated wetland and wetland with a mean water table at 3 and $9 \mathrm{~cm}$ below the soil surface.

- The flux density, which is computed following from Walter et al. (2001a) and Ringeval et al. (2010) and results from three processes: production, oxidation and transport (via diffusion, ebullition and through plants).

A summary of the ORCHIDEE methodology used to compute $\mathrm{CH}_{4}$ emissions is given in Wania et al. (2013).

The wetland emissions are driven by the CRU-NCEP climate forcing dataset (Viovy and Ciais, 2009). In this study, four scenarios of wetland emissions are given based on:

- accounting or not for the non-saturated wetlands (i.e. all classes of wetlands or saturated wetlands only)

- multiplying or not the simulated wetland area by peatland map in boreal regions. This map is obtained by using soil organic carbon data from IGBP DIS at high resolution $\left(5^{\prime} \times 5^{\prime}\right)$, by dividing each pixel of this database by $130 \mathrm{~kg} \mathrm{~m}^{-3}$ (which is the maximum soil carbon density of peat), and then by regridding the result at $1^{\circ} \times 1^{\circ}$ resolution (Lawrence and Slater, 2007). The hypothesis underlying the multiplication of the two products (map of peat-land cover and map of inundated areas) is that the inundated fraction is the same for an entire grid-cell as for a sub-grid peat-land into this grid-cell (see Bousquet et al., 2011 for more details).

The four scenarios lead to a few differences in the latitudinal distributions of wetland emissions in the Tropics and at high latitudes (Fig. 2).

ORCHIDEE provides $\mathrm{CH}_{4}$ emissions by natural wetlands as the product of a flux density by a wetland extent, at a $1^{\circ}$ resolution for the time period 1990-2009.

ORCHIDEE has been evaluated by comparisons to datasets at various spatial scales. At the local scale, the simulated $\mathrm{CH}_{4}$ flux densities have been compared to the measurements available on a few sites (Ringeval et al., 2010). At the regional and global scales, the simulated time variability of wetland extent has been evaluated against remote-sensing products such as Papa et al. (2010) (which is a previous version of the dataset described by Prigent et al. (2012) and used in the current study) (Ringeval et al., 2012). ORCHIDEE has also been used to simulate wetland $\mathrm{CH}_{4}$ emissions in the past (Ringeval et al., 2013) and in the future (Ringeval et al., 2011; Koven et al., 2011).

ORCHIDEE also participated in an inter-comparison of global wetland $\mathrm{CH}_{4}$ emission models: the WETCHIMP inter-comparison, detailed in Melton et al. (2013) and Wania et al. (2013).

The WETCHIMP inter-comparison highlighted the large range in the main patterns of global wetland $\mathrm{CH}_{4}$ emissions 
estimated by the various bottom-up models; it also highlighted the limitations of the currently available datasets of observed wetland methane emissions to evaluate the B-U approach. Therefore, even though the magnitude of global wetland emissions simulated by ORCHIDEE is at the up end of the range of the WETCHIMP models $\left(264 \mathrm{Tg} \mathrm{yr}^{-1}\right.$ against mean of models at $190 \mathrm{Tg} \mathrm{yr}^{-1}$ ), using ORCHIDEE makes sense. Moreover, among the global models participating to WETCHIMP, ORCHIDEE is characterised by its prognostic computation of wetland extent through the use of a TOPMODEL approach. Given the role played by the wetland extent on the inter-annual variability (IAV) of wetland methane emissions (e.g. Bloom et al., 2010), such a prognostic scheme makes ORCHIDEE a particularly interesting tool to investigate the IAV of wetland methane emissions. For this study, the ORCHIDEE simulations for WETCHIMP which focused on 1993-2004 have been extended to 2009.

Since the WETCHIMP inter-comparison underlined the limitations of the currently available datasets of observed wetland $\mathrm{CH}_{4}$ emissions to evaluate the $\mathrm{B}-\mathrm{U}$ approach, this questions our ability to model global wetland $\mathrm{CH}_{4}$ emissions with confidence. The comparison to inverse modelling results is therefore a way to reach a better understanding of the behaviour of ORCHIDEE, particularly regarding the year-toyear variability of wetland emissions due to wetland extent.

Note that ORCHIDEE emissions are not used as prior emissions in the inversions described hereafter.

\subsection{Inverse methods}

The two inversion models used here are based on the Bayesian formalism: they assimilate surface observations of $\mathrm{CH}_{4}$ and methyl-chloroform $\left(\mathrm{CH}_{3} \mathrm{CCl}_{3}\right.$ or MCF) concentrations (measurements from various surface monitoring networks: AGAGE (Prinn et al., 2000, 2012), CSIRO (Francey et al., 1999), EC (Worthy et al., 1998), ENEA (Artuso et al., 2007), AEMET (Gomez-Pelaez et al., 2010), JMA (Matsueda et al., 2004), LSCE (Schmidt et al., 2005), NIWA (Lowe et al., 1991), NOAA/ESRL (NOAA, 2012), SAWS (Brunke et al., 2001), UBA (UBA), as available on the World Data Center for Greenhouse Gases (2012)) into the LMDZ global circulation model (Hourdin et al., 2006) with prior information on the spatio-temporal distribution and uncertainties of $\mathrm{CH}_{4}$ sources and sinks to estimate the magnitude and the uncertainties of optimised surface emissions. The two methods differ by the inversion set-up and the resolution method: see Bousquet et al. (2005) and Pison et al. (2009).

The analytical scheme (hereafter INVANA) is described in more details in Bousquet et al. (2005, 2011). Briefly, it solves for monthly emissions for nine types of sources and sinks (natural wetlands, termites, rice paddies, waste, animals, gas, oil and coal, ocean (including geological), biomass and biofuel burning) in ten land regions plus one global ocean. The constraints are monthly mean $\mathrm{CH}_{4}$ concentrations at 68 surface stations (CSIRO (Francey et al., 1999),
LSCE (Schmidt et al., 2005), NOAA/ESRL (Dlugokencky et al., 1994, 2009), Fig. 1) with monthly uncertainties ranging from $\pm 5 \mathrm{ppb}$ to $\pm 50 \mathrm{ppb}$, with a median of $\pm 10 \mathrm{ppb}$. The transport model is LMDZt v3 off-line nudged on analysed horizontal winds (Uppala et al., 2005; Hourdin et al., 2006) with $\mathrm{OH}$ pre-optimised using methyl-chloroform concentrations (Bousquet et al. (2005) used MCF concentration measurements by AGAGE (Prinn et al., 2005) and NOAA/ESRL (Montzka et al., 2000, 2011)). The prior emissions are elaborated from various inventories by Matthews and Fung (1987) or Kaplan (2002), Olivier and Berdowski (2001) and van der Werf et al. (2006). The prior wetland emissions are based on Matthews and Fung (1987) for ten of the 11 scenarios and on Kaplan (2002) for the eleventh scenario, in order to assess the influence of wetland distribution. Their latitudinal distribution is either consistent with ORCHIDEE at high latitudes (more than $30^{\circ}$ South or North, Fig. 2) or in the Tropics ("Kaplan" in Fig. 2) but not both. Monthly uncertainties on fluxes are set at $150 \%$ in each region; there are no error correlations between different regions or months but month-tomonth changes are limited to $\pm 250 \%$ if the process follows a seasonal cycle or to $\pm 50 \%$ otherwise (Peylin et al., 2000, 2002).

The main advantage of this inversion scheme is the low cost of computation, which makes it possible to test various scenarios, varying the time distribution of $\mathrm{OH}$ concentrations, prior errors on observations and on fluxes, the prior distribution of wetlands for instance but also the constraints. In this study, eleven scenarios are used, as described in Bousquet et al. (2011). The eleven scenarios provide a range of analysed fluxes which gives an insight into the impact of the prior assumptions on the results uncertainties, even though it does not represent all the possible causes of errors.

The variational scheme (hereafter INVVAR) is described in Chevallier et al. (2005); Pison et al. (2009); it is an evolution of the analytical scheme. Briefly, it solves for weekly net emissions at grid-point resolution $\left(2.5^{\circ} \times 3.75^{\circ}\right)$. The interest of INVVAR is then that it works at a finer spatial and time resolution than INVANA. The constraints are daily mean observations at continuous measurement stations by AGAGE for $\mathrm{CH}_{4}$ (Rigby et al., 2008) and MCF (Prinn et al., 2005) and flask and $24 \mathrm{~h}$ averaged data for $\mathrm{CH}_{4}$ and MCF by CSIRO (Francey et al., 1999), EC (Worthy et al., 1998), ENEA (Artuso et al., 2007), AEMET (Gomez-Pelaez et al., 2010), JMA (Matsueda et al., 2004), LSCE (Schmidt et al., 2005), NIWA (Lowe et al., 1991), NOAA/ESRL (Montzka et al., 2000, 2011; Dlugokencky et al., 1994, 2009), SAWS (Brunke et al., 2001), UBA (UBA) (Fig. 1). All methane data were re-scaled to the NOAA 2004 methane standard scale (Dlugokencky et al., 2005). The differences in MCF scales have been included in the errors associated to MCF observation error statistics, i.e. in the variances attributed to the differences between measured and simulated MCF concentrations. The chemistry-transport model is LMDZt v4-SACS (Pison et al., 2009) with prior $\mathrm{OH}$ fields provided by a full-chemistry 

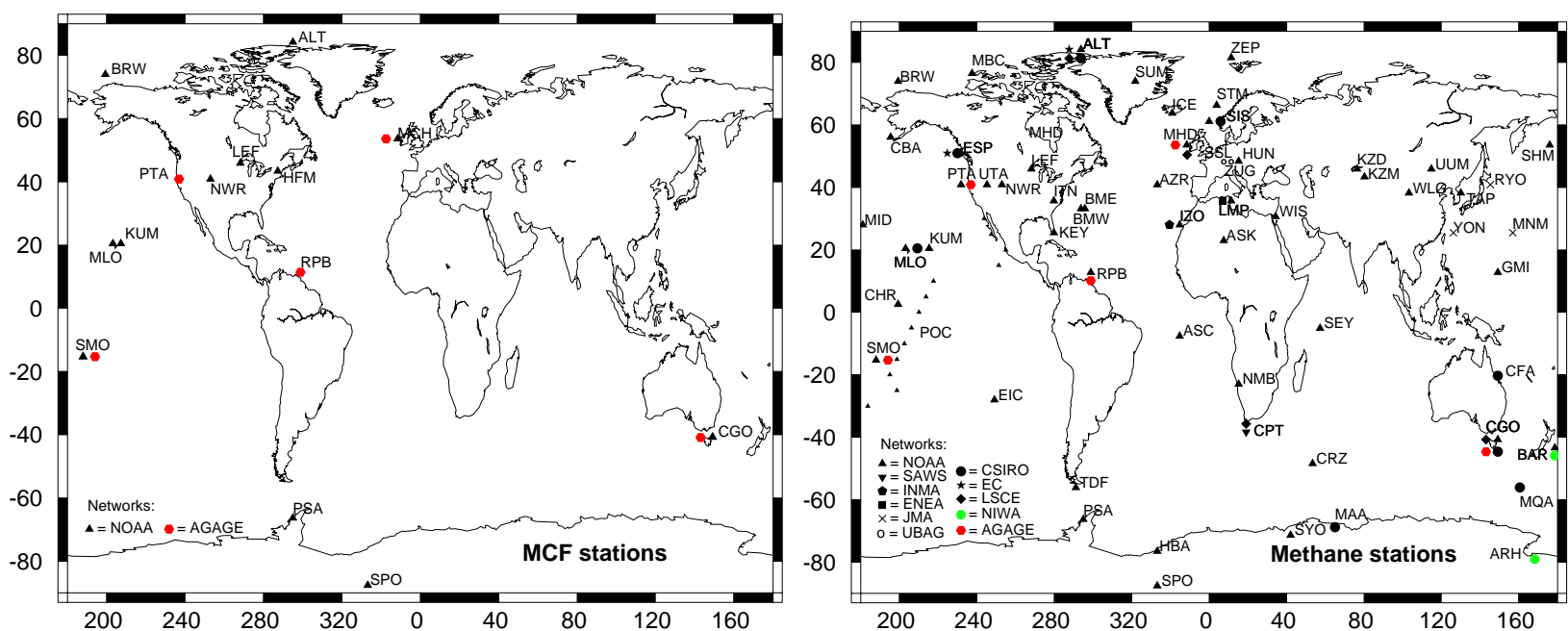

Fig. 1. Surface stations used by the inversions. MCF stations used to constrain $\mathrm{OH}$ concentrations in the variational scheme (INVVAR) only. Smaller triangles for POC denotes the axis of the mobile measurements made on ships in the Pacific Ocean between $30^{\circ} \mathrm{S}-25^{\circ} \mathrm{N}$ and $155-105^{\circ} \mathrm{E}$.
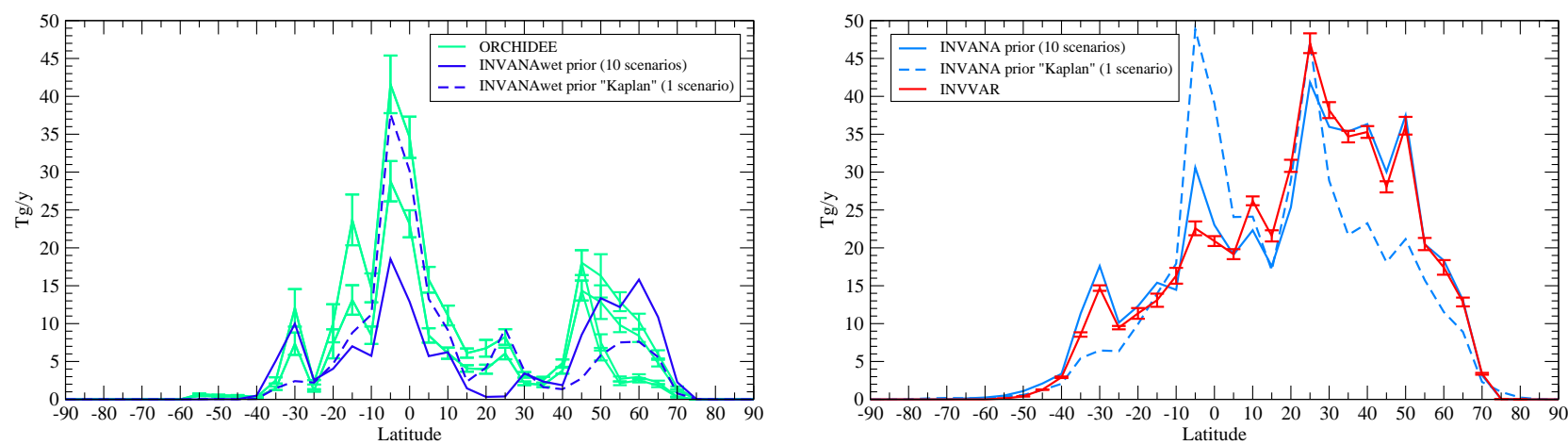

Fig. 2. Latitudinal distributions of prior methane emissions per 5 degrees of latitude: wetland prior emissions (left) used in INVANAs (same every year; same based on Matthews and Fung (1987) for ten scenarios (solid line) and different one based on Kaplan (2002) for the last one (dashed line), see text for details) and ORCHIDEE emissions for each of the four scenarios (average and standard deviation over the 20 years); total net prior emissions (right) used in INVANAs and INVVAR (average and standard deviation over the 20 years, variations due to biomass burning).

run with the INCA scheme (Hauglustaine et al., 2004; Folberth et al., 2005). $\mathrm{OH}$ and $\mathrm{CH}_{4}$ are then optimised simultaneously. Prior emissions are elaborated from inventories by Fung et al. (1991), Olivier and Berdowski (2001) and van der Werf et al. (2006) plus Montzka et al. (2000) re-scaled for MCF. The total net prior emissions for methane are close to those used in 10 INVANAs but between $-10^{\circ} \mathrm{S}-10^{\circ} \mathrm{N}$ (Fig. 2). Note that the inter-annual variations in the prior are small since only the variations due to biomass burning are taken into account. The prior variances of $\mathrm{CH}_{4}$ fluxes are set at $\pm 100 \%$ of the maximum flux over the grid cell and its eight neighbours; error correlations are modelled using correlation lengths $(500 \mathrm{~km}$ on land, $1000 \mathrm{~km}$ on oceans) without time correlations (Chevallier et al., 2005).
The main advantage of this inversion scheme is that there is no aggregation errors but it has a high computing cost.

To summarize,

- INVANA makes use of the prior information on spatiotemporal distributions of $\mathrm{CH}_{4}$ fluxes in large regions to retrieve the emissions due to various processes at a monthly time resolution;

- INVVAR solves for $\mathrm{CH}_{4}$ fluxes at a high temporal and spatial resolution but not enough information is available at these relatively fine scales to discriminate between processes and therefore only the total net flux is estimated. 
Both inversion schemes use the same transport model and the same set of $\mathrm{CH}_{4}$ surface stations, although INVVAR can assimilate individual observations whereas INVANA assimilates monthly means. As the set of stations and the chemistrytransport model are two of the major causes of uncertainties in inversions, it is possible to compare the fluxes analysed by INVANA and INVVAR, notwithstanding the differences between the two (time and space resolutions of fluxes, error correlations, solving for different source categories or net emissions for instance).

The set of $\mathrm{CH}_{4}$ surface stations used by both inversions (Fig. 1) is not evenly distributed over the globe. The coverage is particularly sparse in South America, in the centre of Africa, in Southeast Asia (India, China and Indonesia) and in boreal Eurasia, all of which are key-areas for methane emissions (and particularly, methane emissions due to wetlands). For inversion schemes, the constraints on emission fluxes provided by atmospheric concentrations measured after transport took place for several days are not as strong as the constraints obtained by measurements made in the immediate neighbourhood of the emitting area would be.

We mainly focus our analysis on the inter-annual variations of anomalies of $\mathrm{CH}_{4}$ fluxes: monthly anomalies are deseasonalized by computing 12 month running means and subtracting the deseasonalized mean for the reference period 1993-2007; yearly anomalies are computed by averaging fluxes over each year and subtracting the 1993-2007 average. 1993-2007 is chosen as the reference because satellite data used for additional tests (see Fig. 5) are available during this period so that it is the longest time-period covered by all our estimates. Note that almost all inter-annual variations are inferred from the atmospheric data since in INVANA, prior emissions are assumed to be the same each year and in INVVAR, only biomass burning emissions are prescribed with an inter-annual variability. The anomalies of the net total fluxes (to the atmosphere) are computed from INVVAR and from INVANA (the fluxes per process categories are summed up into a net budget); the $\mathrm{CH}_{4}$ wetland emission anomalies are computed from INVANA (using only the natural wetland category) and from ORCHIDEE. In the following, unless otherwise specified, the \pm ranges given after INVANA (respectively ORCHIDEE) figures are actually the standard deviation over the 11 (respectively 4) scenarios; since INVVAR consists in only one case, no such range is given.

\section{Results}

\subsection{Global emissions}

The total net emissions are distributed similarly in INVANA and INVVAR as displayed in Table 1; the wetland emissions are also similarly distributed in INVANA and ORCHIDEE. Variations in the latitudinal distribution of wetlands in OR-
Table 1. Latitudinal distributions (in \% of the totals) for net emissions by INVVAR and INVANA and wetland emissions by INVANA and ORCHIDEE. The ranges are the standard deviations over the 11 INVANAs and the 4 ORCHIDEE scenarios.

\begin{tabular}{lrr|rr}
\hline \multirow{2}{*}{ Latitude } & \multicolumn{2}{c|}{ Total net emissions } & \multicolumn{2}{c}{ Wetland emissions } \\
\cline { 2 - 5 } & INVVAR & INVANA & INVANA & ORCHIDEE \\
\hline $50-90^{\circ} \mathrm{N}$ & 17 & $16 \pm 1$ & $21 \pm 3$ & $11 \pm 7$ \\
$30-50^{\circ} \mathrm{N}$ & 27 & $26 \pm 2$ & $11 \pm 2$ & $14 \pm 2$ \\
$<30^{\circ} \mathrm{N}$ & 56 & $58 \pm 2$ & $67 \pm 4$ & $75 \pm 6$ \\
\hline
\end{tabular}

CHIDEE are significant ( $\pm 7 \%$ and Fig. 2 ) and due to the use or not of a soil carbon map overlaid to the wetland extent given by ORCHIDEE to reduce the simulated $\mathrm{CH}_{4}$ emitting areas to peat-lands (see Sect. 2.1).

At the global scale, the inter-annual variations of the total net $\mathrm{CH}_{4}$ fluxes of INVVAR and the various INVANAs are in good agreement, in the phasing through time and in the magnitude with time correlations ranging from $66 \%$ to $84 \%$ over the 19 common years (Fig. 3, top). Since these correlations are for deseasonalized anomalies, which are a relatively small signal, they are considered good. This result is not simply a check of a correct mass balance as the two inversions use different $\mathrm{OH}$ fields and different approaches to optimise the atmospheric sink of $\mathrm{CH}_{4}$ (off-line in INVANA or simultaneously in INVVAR). INVVAR retrieves a lower variability than INVANA with standard deviations over all monthly anomalies of 12 and $18 \mathrm{Tg} \mathrm{yr}^{-1}$ respectively. The standard deviation for wetlands in INVANA is $16 \mathrm{Tg} \mathrm{yr}^{-1}$, which indicates that wetlands explain about $90 \%$ of the variability of total methane emissions inferred with INVANA. In the following sections, we therefore focus on changes in natural wetland emissions.

INVVAR and INVANA show negative anomalies after the 1991 Pinatubo eruption (minima of -19 and -20 to $-41 \mathrm{Tg} \mathrm{yr}^{-1}$ in 1992 for respectively INVVAR and INVANA, Fig. 3 top), in agreement with the literature. These anomalies are mainly due to the contribution of the tropical areas (minima for latitudes less than $30^{\circ} \mathrm{N}$ of $-21 \mathrm{Tg} \mathrm{yr}^{-1}$ for INVVAR and -19 to $-35 \mathrm{Tg} \mathrm{yr}^{-1}$ for the 11 INVANA scenarios in 1992, Fig. 3). This is consistent with the negative impact of this volcanic event on wetland $\mathrm{CH}_{4}$ emissions already noticed in the literature (Hogan and Harriss, 1994). The one INVANA scenario producing smaller changes in global and tropical emissions is the one assuming constant $\mathrm{OH}$ concentrations with time; it is closer to INVVAR in the early 1990s. In INVANA, the optimised OH concentrations are sensitive to the errors on MCF emissions, which are proportional to MCF fluxes. Since MCF emissions are large during the 1980-90s, their errors are also large and INVANA find large year-to-year $\mathrm{OH}$ changes (up to $-15 \%$ for the total column between 1996 and 1997 for one scenario). In INVVAR, since the optimisation is simultaneous, 
$\mathrm{OH}$ concentrations are constrained by both $\mathrm{MCF}$ and $\mathrm{CH}_{4}$ measurements. Therefore, $\mathrm{OH}$ variability is smaller than in most INVANA scenarios, closer to the constant-OH one, and more consistent with Montzka et al. (2011).

A large positive anomaly of global total emissions is inferred by INVVAR and INVANA in 1997-1999 (maxima at +37 and +19 to $+25 \mathrm{Tg} \mathrm{yr}^{-1}$ respectively, Fig. 3 top), related to the El-Niño/La-Niña events. Most of the signal comes from tropical regions (maxima at +27 and +16 to $+22 \mathrm{Tg} \mathrm{yr}^{-1}$ in INVVAR and the INVANAs). That could be linked to fires in 1997-98 (van der Werf et al., 2004) and exceptionally high $\mathrm{CH}_{4}$ emissions from natural wetlands during LaNiña event in 1998 (Hodson et al., 2011). These high wetland emissions are actually consistent with 1998 natural wetland emissions as seen by ORCHIDEE, with anomalies of +11 to $+17 \mathrm{Tg} \mathrm{yr}^{-1}$ at the global scale (Fig. 3) and +12 to $+17 \mathrm{Tg} \mathrm{yr}^{-1}$ in the tropical regions (Fig. 3 bottom). Note that for the four ORCHIDEE scenarios, only two curves appear on Fig. 3 bottom since the differences obtained by varying boreal peat-lands do not impact the tropical emissions.

More challenging to understand is the mismatch between INVANA and ORCHIDEE wetland emissions between 2000 and 2006 (Fig. 3, 3rd graph from top). The median time correlation between all ORCHIDEE and all INVANA scenarios is $45 \%$ over $1990-2009$, but reaches $68 \%$ if the period 2000-2006 is excluded from the computation. Moreover, if the trends of both ORCHIDEE and INVANA are positive between 1992 and $1999\left(+4.7 \pm 1.0 \mathrm{Tg} \mathrm{yr}^{-1}\right.$ and $+4.7 \pm 0.7 \mathrm{Tg} \mathrm{yr}^{-1}$ respectively), ORCHIDEE infers a stable to positive trend between 2000 and $2006\left(+2.0 \pm 0.4 \mathrm{Tg} \mathrm{yr}^{-1}\right)$ whereas INVANA infers a negative trend over the same period $\left(-4.2 \pm 1.2 \mathrm{Tg} \mathrm{yr}^{-1}\right)$. To assess the cause of this discrepancy between the two approaches, we studied the regional distributions of methane emissions.

\subsection{Latitudinal and regional break-down of emissions south of $30^{\circ} \mathrm{N}$}

We find that the disagreement between ORCHIDEE and INVANA at the global scale after 2000 is mainly due to the anomalies south of $30^{\circ} \mathrm{N}$, an area where emissions are mainly due to tropical land regions (Fig. 3). Of the four ORCHIDEE scenarios described previously, only two are relevant in the Tropics (the other two are obtained by varying boreal peat-lands) and are thus retained in the following: ORCHIDEE-all accounting for all classes of wetlands and ORCHIDEE-sat accounting only for saturated wetlands. In this latitudinal band, the signs of the anomalies from 1991 to 2000 for total emissions by the two inversions on the one hand and for wetland emissions by INVANA and ORCHIDEE on the other hand are broadly in agreement. From 2000, and particularly between 2003 and 2006, ORCHIDEE provides anomalies with a sign opposite to the one of INVANA. For example, in 2005 the anomaly at these latitudes is
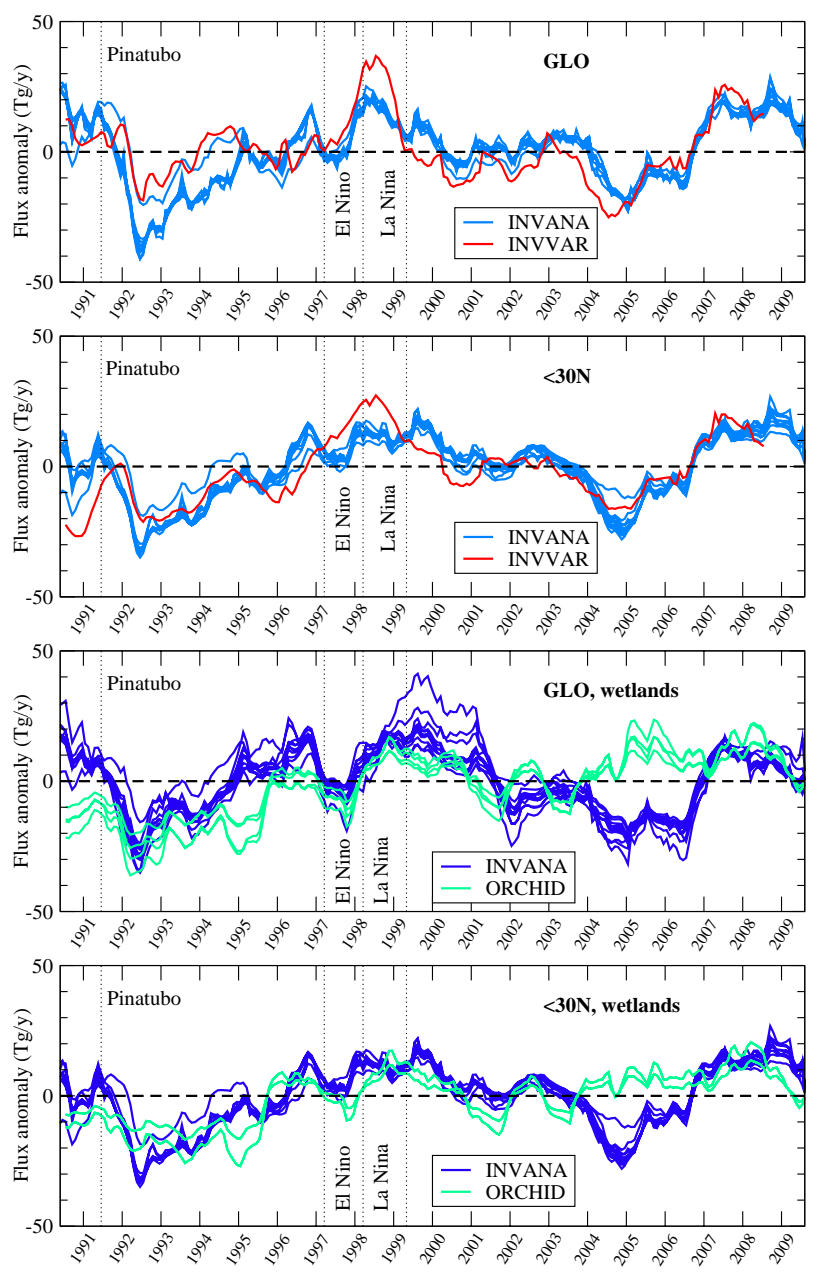

Fig. 3. Deseasonalized monthly anomalies for methane emissions. Total net emissions are given by INVVAR and INVANA. Natural wetland emissions are given by INVANA and ORCHIDEE. Anomalies are shown for the whole globe ("GLO") and for the latitudes less than $30^{\circ} \mathrm{N}$ only (" $<30^{\circ} \mathrm{N}$ "). As detailed in Sect. 2, there are 11 scenarios for INVANA (in light and dark blue for total and wetland emissions) and 4 scenarios for ORCHIDEE (in green).

+3 to $+13 \mathrm{Tg} \mathrm{yr}^{-1}$ in ORCHIDEE versus -6 to $-26 \mathrm{Tg} \mathrm{yr}^{-1}$ in INVANA (Fig. 3 bottom).

Moreover, the trend over 2000-2006 in this band (Table 2) is $-4.1 \pm 0.9 \mathrm{Tg} \mathrm{yr}^{-1}$ for INVANA whereas the trend for the mean between ORCHIDEE-all (scenario accounting for all wetlands) and ORCHIDEE-sat (scenario with saturated wetlands only) is $+1.4 \pm 0.3 \mathrm{Tg} \mathrm{yr}^{-1}$ (Table 2).

In order to investigate the regional contributions to the flux anomalies and trends of wetland emissions in the Tropics, we computed the yearly flux anomalies for ORCHIDEE and the mean of the eleven scenarios of INVANA for eight keyregions south of $30^{\circ} \mathrm{N}$ (Fig. 4). Interestingly, ORCHIDEE and INVANA agree on the fact that variations in methane emissions from the Amazon basin (tropical South America in Fig. 4) drive the trend of tropical emissions of methane. 
Table 2. Trends for ORCHIDEE and INVANA. Slope in $\mathrm{Tg} \mathrm{yr}^{-1}$; std=standard deviation; ratio $S=$ ratio of the trends over $2000-2006$ for tropical South America to the whole less than $30^{\circ} \mathrm{N}$ (in \%).

\begin{tabular}{|c|c|c|c|c|c|c|}
\hline \multirow{2}{*}{$\begin{array}{l}\text { Scenarios } \\
\text { Region }\end{array}$} & \multicolumn{3}{|c|}{ mean of ORCHIDEE-all and ORCHIDEE-sat } & \multicolumn{3}{|c|}{ mean of all 11 INVANAs } \\
\hline & slope & $R^{2}$ & ratio $S$ & slope & $R^{2}$ & ratio $S$ \\
\hline global & $\begin{array}{l}1.4 \\
(\mathrm{std}=0.3)\end{array}$ & $\begin{array}{l}0.1 \\
(\mathrm{std}=0.0)\end{array}$ & - & $\begin{array}{l}-4.4 \\
(\mathrm{std}=1.1)\end{array}$ & $\begin{array}{l}0.8 \\
(\mathrm{std}=0.1)\end{array}$ & - \\
\hline$<30^{\circ} \mathrm{N}$ & $\begin{array}{l}1.4 \\
(\mathrm{std}=0.3)\end{array}$ & $\begin{array}{l}0.2 \\
(\mathrm{std}=0.0)\end{array}$ & - & $\begin{array}{l}-4.1 \\
(\mathrm{std}=0.9)\end{array}$ & $\begin{array}{l}0.7 \\
(\mathrm{std}=0.1)\end{array}$ & - \\
\hline Amazon region only & $\begin{array}{l}1.3 \\
(\mathrm{std}=0.3)\end{array}$ & $\begin{array}{l}0.2 \\
(\mathrm{std}=0.0)\end{array}$ & $\begin{array}{l}93 \\
(\mathrm{std}=0.9)\end{array}$ & $\begin{array}{l}-3.9 \\
(\mathrm{std}=1.3)\end{array}$ & $\begin{array}{l}0.8 \\
(\operatorname{std}=0.0)\end{array}$ & $\begin{array}{l}95 \\
(\mathrm{std}=22.3) \\
\text { excl. scenario } \\
\text { based on Kaplan's } \\
\text { prior:89 }(\mathrm{std}=11.3)\end{array}$ \\
\hline
\end{tabular}
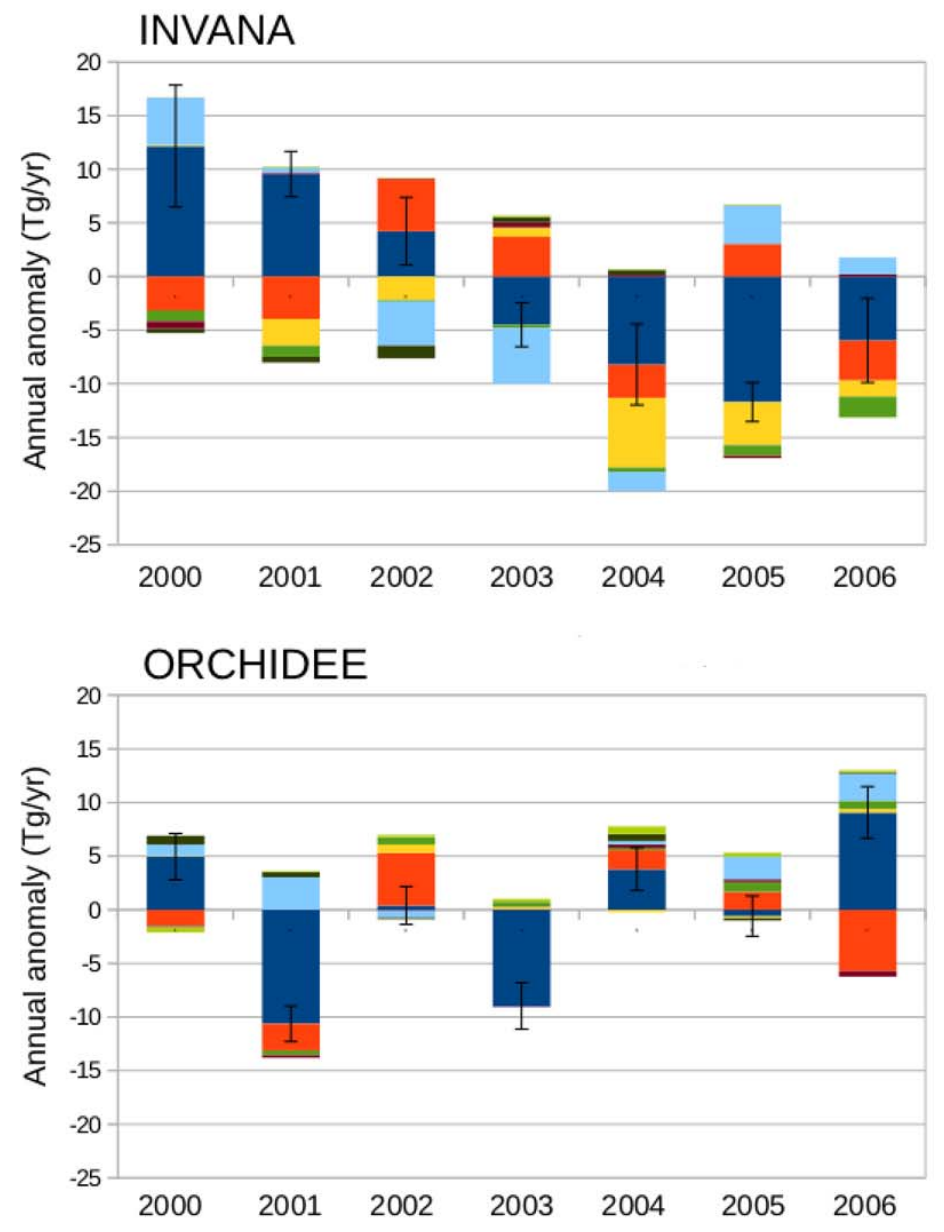

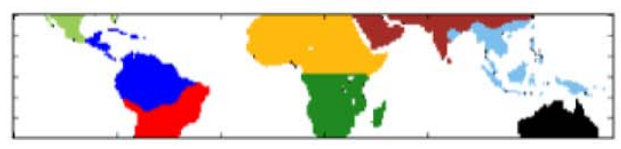

- Australia

Tropical Asia

Temperate Asia

- Southern Africa

Northern Africa

- Southern South America

- North America

- Tropical South America

Fig. 4. Yearly anomalies of methane wetland emissions from 2000 to 2006 in eight areas in the Tropics. The distributions are shown for ORCHIDEE and the mean of the 11 INVANA scenarios. The "error bars" on the tropical South America region are computed from (i) the difference between the 11 scenarios for INVANA and (ii) the difference between the scenario with all wetlands and the one with saturated wetlands only for ORCHIDEE. 

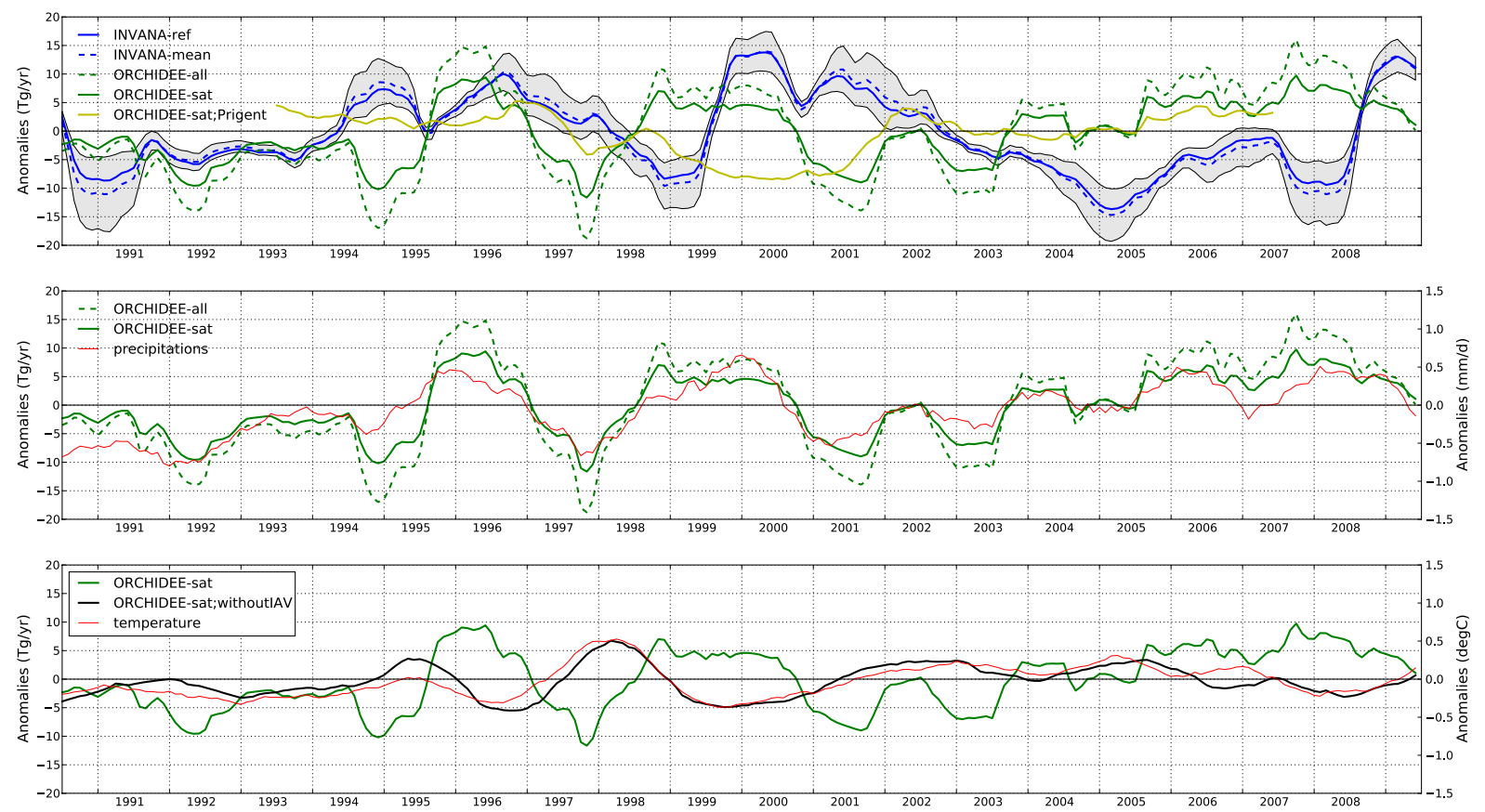

Fig. 5. Monthly anomalies of $\mathrm{CH}_{4}$ wetland emissions, precipitations and temperature in tropical South America (see map in Fig. 4). ORCHIDEE-all = ORCHIDEE scenario accounting for all classes of wetlands; ORCHIDEE-sat = ORCHIDEE scenario with only saturated wetland; "ORCHIDEE-sat;Prigent" = ORCHIDEE scenario where the inter-annual variability of the ORCHIDEE-computed wetland extent is replaced by the one by Papa et al. (2010); "ORCHIDEE-sat;without IAV" = ORCHIDEE scenario where the inter-annual variability of the wetland extent is removed.

Indeed, the ratio between the slopes for tropical South America and the whole region south of $30^{\circ} \mathrm{N}$ (Table 2) indicates that tropical South America explains $93 \%$ of the trend for ORCHIDEE and between 89 and $95 \%$ in INVANA (depending on the scenarios). However, the sign of the trends is opposite between ORCHIDEE and INVANA: the inferred trends for the Amazon region are $-3.9 \pm 1.3 \mathrm{Tg} \mathrm{yr}^{-1}$ for INVANA and $+1.3 \pm 0.3 \mathrm{Tg} \mathrm{yr}^{-1}$ for ORCHIDEE (Table 2). Note that for this area, the optimised total net emissions retrieved by INVVAR stay close to the prior, i.e. display no trend; the only differences with the prior appear in the seasonal time profile, with higher emission peaks, particularly in AugustSeptember 2005 (a dry year (Frappart et al., 2012) with exceptional fires) and September 2007-2008.

When an atmospheric inversion cannot provide insights about the underlying emission processes and the sensitivity of wetland emissions to climate, the ORCHIDEE processbased model can. The monthly anomalies of $\mathrm{CH}_{4}$ wetland emissions for the Amazon region for ORCHIDEE and INVANA, together with the precipitations and temperature changes are shown in Fig. 5. Not surprisingly, ORCHIDEE and INVANA phases of the inter-annual variations are not in agreement at this regional scale, although the magnitudes of the changes are consistent. As noted before, the trends between 2000 and 2006 are opposite for ORCHIDEE (positive) and INVANA (negative) (Fig. 5, top panel).
Wetland extent is a key element in process-model algorithms (Melton et al., 2013). Therefore, in addition to ORCHIDEE-sat where some TOPMODEL concepts are used to compute the variability in time of the wetland extent (Ringeval et al., 2012), we introduced an ORCHIDEE estimate where this variability is prescribed by the dataset of satellite-based inundated areas given by Prigent et al. (2012). The aim of using this dataset instead of the mechanistic model for wetland extent is to evaluate the sensitivity of the emission trend (and particularly, of its sign) to the representation of the wetland extent. Whatever the choice of IAV for wetland extent (i.e. computed or prescribed from remote-sensing data), the IAV and the trend in the various ORCHIDEE scenarios are positive and are never close to INVANA's (Fig. 5, upper panel). Interestingly, changing the description of the wetland extent significantly impacts the phasing and the magnitude of the year-to-year variations inferred by ORCHIDEE (Fig. 5, e.g. the 1998-2003 period). Nevertheless, both descriptions lead to a consistent positive trend between 2000 and $2006\left(+1.7 \mathrm{Tg} \mathrm{yr}^{-1}\right.$ for ORCHIDEEall, $+1.1 \mathrm{Tg} \mathrm{yr}^{-1}$ for ORCHIDEE-sat and $+1.5 \mathrm{Tg} \mathrm{yr}^{-1}$ for "ORCHIDEE-sat;Prigent"), finally, the trend is close to zero for "ORCHIDEE-sat;Prigent" for the period 2002-2005 but remains positive for other ORCHIDEE simulations.

In tropical South America, the trend in ORCHIDEE wetland emissions is driven by precipitations (Fig. 5, middle 
panel), which show a positive trend of $0.05 \mathrm{~mm} \mathrm{~d}^{-1}$ between 2000 and 2006 over the Amazon. When the IAV of wetland extent is removed (black curve in Fig. 5, bottom panel), the IAV of emissions over 1990-2009 decreases from 3.8 (ORCHIDEE-sat) to $2.1 \mathrm{Tg} \mathrm{yr}^{-1}$ and appears to be driven by air temperature with a strong correlation of 0.86 over 1990 2009 (Fig. 5, bottom panel). Temperature could have an effect on flux densities through both methanogenesis rate and substrate supply but large uncertainties remain on the contribution of each process (e.g. White et al., 2008 for northern peat-lands).

\subsection{Discussion}

Overall, ORCHIDEE infers an increase of $\mathrm{CH}_{4}$ emissions in the Amazon between 2000 and 2006, which is opposite to the decreasing emissions inferred by INVANA inversions. The difference of IAV between ORCHIDEE-simulated emissions when the time variability of wetland extent is either prescribed or computed (Fig. 5, upper panel) underlines the difficulty to capture a good IAV of the processes involved in the extension/retraction of wetland areas. A way of improvement would be to implement the floodplains into the model (e.g. like Decharme et al., 2008, 2012), the relevant processes leading to wetland formation in the Amazon basin (Hess et al., 2003). Uncertainties linked to precipitations (magnitude and spatial distribution) in the Amazon basin and their huge effect on the floodplains extent simulated by land surface models (Guimberteau et al., 2012) is also problematic.

The lack of wetland Plant Functional Type into the ORCHIDEE model and the use of the mean grid-cell simulated labile carbon as methanogenesis substrate's proxy could also lead to an overestimated sensitivity of $\mathrm{CH}_{4}$ emissions to precipitations (Ringeval et al., 2013). However, in our study, the sensitivity of $\mathrm{CH}_{4}$ emissions to precipitations seems to mainly happen through the wetland extent (Fig. 5) and make the lack of floodplain representation the main caveat of the B-U approach used here.

Despite these possible caveats of the ORCHIDEE model, the IAV of the remote-sensed inundated extent in the Amazon basin over 2000-2006 and of the in-situ river discharge are in agreement and do not exhibit a clear negative trend (see Fig. 10a in Papa et al., 2010).

This points out a possible issue with the large negative trend retrieved by INVANA global inversions. Indeed, the Amazon region is poorly constrained by the surface networks, which only provide routine observations over the neighbouring oceans. This lack of nearby observations means that large changes in emissions can be tolerated in the inversion when assimilating these observations. Also, using large regions may induce aggregation errors as explained in Kaminski et al. (2001). It should be noted that for this area INVVAR (which works at the grid cell's scale but only optimises total net emissions) obtains emissions which stay close to the prior, i.e. emissions with no trend. This seems to con- firm that the changes made by INVANA in tropical South America are due to constraints which are not directly relevant to the Amazon basin.

Overcoming the lack of observations requires to assimilate more regional data in the Amazon area (such as aircraft data (L. Gatti, personal communication, 2013; Miller et al., 2007), satellite data (for example SCIAMACHY (Frankenberg et al., 2008), IASI (Crevoisier et al., 2009), GOSAT (Morino et al., 2011) (C. Cressot, personal communication, 2012)). It may then be possible to solve the fluxes at the model's resolution (in INVANA's set-up) or to solve for the different source types in the variational approach (with INVVAR method). Overall, the large negative emission trend inferred in the Amazon basin by INVANA is less likely than the neutral to positive emission trend found by INVVAR and ORCHIDEE.

In INVANA, if not constrained by nearby measurements, the changes in emissions from the Amazon region are indirectly constrained by the global atmospheric growth rate. Global observed concentrations are stable between 2000 and 2006 (Dlugokencky et al., 2009). Bottom-up inventories for anthropogenic emissions give positive trends at the global scale over 2000-2006. For instance, the EDGAR inventory computes a $+8 \mathrm{Tg} \mathrm{yr}^{-1}$ increase in anthropogenic emissions during this period (EDGAR 4, 2009). Consistent with this bottom-up inventory albeit smaller, INVANA infers a $+4 \pm 2 \mathrm{Tg} \mathrm{yr}^{-1}$ increase in anthropogenic emissions for the same period (Bousquet et al., 2011) and, to match the stable global concentration, infers a $-4 \pm 1 \mathrm{Tg} \mathrm{yr}^{-1}$ decrease in emissions, mostly, as stated before, due to South America wetland emissions. If the increase in anthropogenic $\mathrm{CH}_{4}$ emissions is real, a decreasing source or an increasing sink must be identified to match the stable concentrations at the global scale. There is no indication of a positive trend in $\mathrm{OH}$ concentrations after 2000 that could have induced an abnormally increasing methane loss in the troposphere (Rigby et al., 2008; Montzka et al., 2011). The increasing wetland emissions found by ORCHIDEE indicate that South America might only be an opportunistic candidate for INVANA to reduce emissions and that another region and/or another process is actually decreasing. The analyses of ${ }^{13} \mathrm{C}$ in $\mathrm{CH}_{4}$ recently brought elements to the debate. The possible decrease in microbial-related emissions in the Northern Hemisphere since the 1990s inferred by (Kai et al., 2011) is contested by the analysis of another more consistent 13C dataset, which infers no trend in the inter-hemispheric difference of $13 \mathrm{C}$ (Levin et al., 2012). This last result questions the validity of the large increase in anthropogenic methane emissions computed by the EDGAR inventory for the early 2000s. Analysis of ethane emissions (Aydin et al., 2011; Simpson et al., 2012) or another inventory (IIASA, Lamarque et al. (2010)) also point in the direction of non-increasing fossil-fuel-related emissions in the early 2000s. The recent synthesis brought by Kirschke et al. (2013) at the global scale also suggests stable to slightly increasing fossil fuel emissions in the early 
2000s. Overall, the probably too large negative trend in wetland emissions in INVANA suggests a possible overestimation of the positive trend in anthropogenic methane emissions given by inventories.

\section{Conclusions}

In this study, we bring together two "top-down" (T-D) and one "bottom-up" (B-U) approaches providing surface methane emissions.

The T-D and B-U visions of methane emissions agree on two key-points at the global scale:

- the time-phasing of the anomalies of total and wetland methane fluxes from 1990 to 2000

- the inter-annual variability of total and wetland methane emissions.

The process-discriminating T-D method indicates that wetlands dominate the time-variability of these global methane emissions.

As in previous studies, particular events can be identified: the post-Pinatubo years illustrate the impact of tropical wetlands through negative anomalies; the alternate 1997-1998 El-Niño/1998-1999 La-Niña illustrate the qualitative agreement of all methods with a large impact of wetlands.

At a finer scale, the T-D and B-U visions are in agreement on:

- the inter-annual variability of total and wetland methane emissions in the Tropics

- the fact that tropical South America is a key region to explain the trends in methane emissions.

Nevertheless, a period of poor agreement between the two approaches is found between 2000 and 2006, during the stagnation of methane atmospheric concentrations. A regional analysis shows that this is mostly due to discrepancies in tropical South America wetland emissions. In this key region, the proposed trends for wetland emissions are of opposite signs: positive for the process-based ORCHIDEE model, negative for one inversion; it is neutral for the inversion not solving for individual processes.

The neutral to positive trend of wetland emissions seems to be the most probable scenario because:

- it is found under various assumptions by ORCHIDEE and is consistent with analysed precipitations and the satellite-derived extent of inundated areas

- the inversions lack constraints in this area, because there is no station assimilated inland South America and the atmospheric network is sparse in the Tropics.

Among the consequences of an increase of wetland emissions between 2000 and 2006, is the need to revisit the large increase in anthropogenic emissions computed by some inventories for the early 2000s (e.g. EDGAR4) since this somehow signifies a decreasing source to compensate and match the stable observed methane concentrations.

As stated by Kirschke et al. (2013), the global methane cycle remains uncertain, which limits our ability to draw definitive conclusions about the changes in surface emissions, at least over the last $15 \mathrm{yr}$. Increasing the confidence in the emission trends and anomalies goes with improving B-U models and T-D inversions. This work allows us to suggest priority actions in this matter.

\section{Recommendations}

Regarding B-U approaches, we suggest first to extend the time-period covered by the WETCHIMP inter-comparison to include the 2004-2006 period and to regionalize the intercomparison to the Amazon basin scale. The range of the global IAVs found by the WETCHIMP models during the 1999-2004 period is large (see Fig. 7 by Melton et al., 2013) and finding a robust trend over the 2000-2006 period is therefore unlikely. However, the combination of the methane flux densities (flux per square metre of wetland) computed by each model with the datasets by Prigent et al. (2012), as done in the present study with ORCHIDEE, could help to better understand the drivers of the simulated IAVs.

Another critical point is to address the sensitivity to the precipitation forcing in more details.

Finally, none of the models participating in the WETCHIMP inter-comparison accounts for floodplain extents. These processes are particularly relevant in regions such as the Amazon basin (Miguez-Macho and Fan, 2012) and should be implemented in B-U models to simulate more accurate methane emissions in the Tropics.

Regarding the methane anthropogenic emissions, an important action concerns the improvements of the trends computed by inventories (e.g. EDGAR4, EPA). This is linked to regular and more robust updates of sectorial activities and emission factors.

Regarding T-D approaches, we suggest to reinforce surface observations and vertical profiles in key regions such as the Amazon Basin, as a key complement to satellite data from GOSAT and IASI.

For all this, the ongoing effort to develop a long-term surface and low-troposphere network in tropical South America is very important and should be sustained (Miller et al., 2007). Future active missions may also add data at higher latitudes with possibly less biases than former passive retrievals (Heimann and Marshall, 2011). As for B-U methods, intercomparisons of models and inversion systems should be used as a tool to assess the degree of confidence of the T-D retrieved methane fluxes.

Finally, we think that confronting T-D and B-U approaches is a fruitful way of learning more about the strengths and the 
weaknesses of the various scenarios proposed to explain the changes in methane emissions of the past decades.

Acknowledgements. We acknowledge the contributors to the World Data Center for Greenhouse Gases for providing their data of methane and methyl-chloroform atmospheric concentrations: AEMET (Agencia Estatal de Meteorologia), AGAGE (Advanced Global Atmospheric Gases Experiment), CSIRO (Commonwealth Scientific and Industrial Research Organisation), Environment Canada, ENEA (Italian National agency for new technologies, Energy and sustainable economic development), JMA (Japan Meteorological Agency), LSCE (Laboratoire des Sciences du Climat et de l'Environnement), NIWA (National Institute of Water and Atmospheric Research), NOAA/ESRL (National Oceanic \& Atmospheric Administration/Earth System Research Laboratory), SAWS (South African Weather Service), UBA (Federal Environment Agency Austria).

The authors contacted all data PIs and in particular thank A. J. Gomez-Pelaez (AEMET); R. G. Prinn, R. F. Weiss, H. J. R. Wang (AGAGE); P. Krummel, R. Langenfelds, P. Steele (CSIRO); D. Worthy (EC); S. Piacentino (ENEA); T. Kawasato (JMA); M. Ramonet, M. Schmidt (LSCE); G. Brailsford (NIWA); E. Dlugokencky, S. A. Montzka, G. Dutton (NOAA); E. Brunke (SAWS); K. Uhse (UBA).

We thank N. Viovy (LSCE) for the data for ORCHIDEE forcings and M. Saunois (LSCE) for fruitful discussions. We wish to thank F. Marabelle and his team for computer support at LSCE.

Edited by: G. Stiller

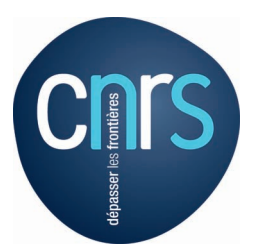

The publication of this article is financed by CNRS-INSU.

\section{References}

Artuso, F., Chamard, P., Piacentino, S., di Sarra, A., Meloni, D., Monteleone, F., Sferlazzo, D., and Thiery, F.: Atmospheric methane in the Mediterranean: analysis of measurements at the island of Lampedusa during 1995-2005, Atmos. Environ., 41, 3877-3888, 2007.

Aydin, M., Verhulst, K. R., Saltzman, E. S., Battle, M. O., Montzka, S. A., Blake, D. R., Tang, Q., and Prather, M. J.: Recent decreases in fossil-fuel emissions of ethane and methane derived from firn air, Nature, 476, 198-201, 2011.

Bândă, N., Krol, M., van Weele, M., van Noije, T., and Röckmann, T.: Analysis of global methane changes after the 1991 Pinatubo volcanic eruption, Atmos. Chem. Phys., 13, 22672281, doi:10.5194/acp-13-2267-2013, 2013.

Bloom, A. A., Palmer, P. I., Fraser, A., Reay, D. S., and Frankenberg, C.: Large-Scale Controls of Methanogenesis Inferred from Methane and Gravity Spaceborne Data, Science, 327, 322-325, doi:10.1126/science.1175176, 2010.

Bousquet, P., Hauglustaine, D. A., Peylin, P., Carouge, C., and Ciais, P.: Two decades of $\mathrm{OH}$ variability as inferred by an in- version of atmospheric transport and chemistry of methyl chloroform, Atmos. Chem. Phys., 5, 2635-2656, doi:10.5194/acp-52635-2005, 2005.

Bousquet, P., Ciais, P., Miller, J. B., Dlugokencky, E. J., Hauglustaine, D. A., Prigent, C., Van der Werf, G. R., Peylin, P., Brunke, E. G., Carouge, C., Langenfelds, R. L., Lathiere, J., Papa, F., Ramonet, M., Schmidt, M., Steele, L. P., Tyler, S. C., and White, J.: Contribution of anthropogenic and natural sources to atmospheric methane variability, Nature, 443, 439443, doi:10.1038/nature05132, 2006.

Bousquet, P., Ringeval, B., Pison, I., Dlugokencky, E. J., Brunke, E.G., Carouge, C., Chevallier, F., Fortems-Cheiney, A., Frankenberg, C., Hauglustaine, D. A., Krummel, P. B., Langenfelds, R. L., Ramonet, M., Schmidt, M., Steele, L. P., Szopa, S., Yver, C., Viovy, N., and Ciais, P.: Source attribution of the changes in atmospheric methane for 2006-2008, Atmos. Chem. Phys., 11, 3689-3700, doi:10.5194/acp-11-3689-2011, 2011.

Brunke, E. G., Labuschagne, C., and Scheel, H. E.: Trace gas variations at Cape Point, South Africa, during May 1997 following a regional biomass burning episode, Atmos. Environ., 35, 777786, 2001.

Chen, Y.-H. and Prinn, R. G.: Estimation of atmospheric methane emissions between 1996 and 2001 using a three-dimensional global chemical transport model, J. Geophys. Res., 111, doi:10.1029/2005JD006058, 2006.

Chevallier, F., Fisher, M., Peylin, P., Serrar, S., Bousquet, P., Bréon, F.-M., Chédin, A., and Ciais, P.: Inferring $\mathrm{CO}_{2}$ sources and sinks from satellite observations: method and application to TOVS data, J. Geophys. Res., 110, D24309, doi:10.1029/2005JD006390, 2005.

Crevoisier, C., Nobileau, D., Fiore, A. M., Armante, R., Chédin, A., and Scott, N. A.: Tropospheric methane in the tropics - first year from IASI hyperspectral infrared observations, Atmos. Chem. Phys., 9, 6337-6350, doi:10.5194/acp-9-6337-2009, 2009.

Cunnold, D., Steele, L., Fraser, P., Simmonds, P., Prinn, R., Weiss, R., Porter, L., O'Doherty, S., Langenfelds, R., Krummel, P., Wang, H., Emmons, L., Tie, X., and Dlugokencky, E.: In situ measurements of atmospheric methane at GAGE/AGAGE sites during 1985-2000 and resulting source inferences, J. Geophys. Res.-Atmos., 107, 4225, doi:10.1029/2001JD001226, 2002.

Decharme, B., Douville, H., Prigent, C., Papa, F., and Aires, F.: A new river flooding scheme for global climate applications: Off-line evaluation over South America, J. Geophys. Res., 113, D11110, doi:10.1029/2007JD009376, 2008.

Decharme, B., Alkama, R., Papa, F., Faroux, S., Douville, H., and Prigent, C.: Global off-line evaluation of the ISBA-TRIP flood model, Clim. Dyn., 38, 1389-1412, doi:10.1007/s00382-0111054-9, 2012.

Dlugokencky, E., Steele, L., Lang, P., and Masarie, K.: The growth rate and distribution of atmospheric methane, J. Geophys. Res., 99, 17021-17043, doi:10.1029/94JD01245, 1994.

Dlugokencky, E., Dutton, E. G., Novelli, P. C., Tans, P. P., Masarie, K. A., Lantz, K. O., and Madronich, S.: Changes in $\mathrm{CH}_{4}$ and $\mathrm{CO}$ growth rates after the eruption of Mt. Pinatubo and their link with changes in tropical tropospheric UV flux, Geophys. Res. Lett., 23, 2761-2764, doi:10.1029/96GL02638, 1996.

Dlugokencky, E., Masarie, K., Lang, P., and Tans, P.: Continuing decline in the growth rate of the atmospheric methane burden, Nature, 393, 447-450, 1998. 
Dlugokencky, E. J., Houweling, S., Bruhwiler, L., Masarie, K. A., Lang, P. M., Miller, J. B., and Tans, P. P.: Atmospheric methane levels off: Temporary pause or a new steady-state?, Geophys. Res. Lett., 30, doi:10.1029/2003GL018126, 2003.

Dlugokencky, E., Myers, R., Lang, P., Masarie, K., Crotwell, A., Thoning, K., Hall, B., Elkins, J., and Steele, L.: Conversion of NOAA atmospheric dry air $\mathrm{CH}_{4}$ mole fractions to a gravimetrically prepared standard scale, J. Geophys. Res., 110, D18306, doi:10.1029/2005JD006035, 2005.

Dlugokencky, E., Bruhwiler, L., White, J., Emmons, L., Novelli, P., Montzka, S., Masarie, K., Crotwell, A., Miller, J., and Gatti, L.: Observational constraints on recent increases in the atmospheric $\mathrm{CH}_{4}$ burden, Geophys. Res. Lett., 36, L18803, doi:10.1029/2009GL039780, 2009.

Dlugokencky, E. J., Lang, P., Masarie, K., Crotwell, A. M., and Bruhwiler, L.: Large Scale Constraints on Methane Emissions Determined from Observations, AGU Fall Meeting Abstracts, p. D6, 2011.

EDGAR 4: Emission Database for Global Atmospheric Research (EDGAR), release version 4.0., European Commission, Joint Research Centre (JRC)/Netherlands Environmental Assessment Agency (PBL), http://edgar.jrc.ec.europa.eu, 2009.

EPA: Global Anthropogenic Non- $\mathrm{CO}_{2}$ Greenhouse Gas Emissions: 1990-2030, U.S. Environmental Protection Agency, Washington, DC 20460, report EPA 430-D-11-003, http://www.epa.gov/ nonco2/econ-inv/international.html, 2011.

Folberth, G., Hauglustaine, D., Ciais, P., and Lathière, J.: On the role of atmospheric chemistry in the global $\mathrm{CO}_{2}$ budget, Geophys. Res. Lett., 32, L08801, doi:10.1029/2004GL021812, 2005.

Francey, R., Steele, L., Langenfelds, R., and Pak, B.: High Precision Long-Term Monitoring of Radiatively Active and Related Trace Gases at Surface Sites and from Aircraft in the Southern Hemisphere Atmosphere, J. Atmos. Sci., 56, 279-285, 1999.

Frankenberg, C., Bergamaschi, P., Butz, A., Houweling, S., Meirink, J., Notholt, J., Petersen, A., Schrijver, H., Warneke, T., and Aben, I.: Tropical methane emissions: A revised view from SCIAMACHY onboard ENVISAT, Geophys. Res. Lett, 35, L15811, doi:10.1029/2008GL034300, 2008.

Frappart, F., Papa, F., da Silva, J. S., Ramillien, G., Prigent, C., Seyler, F., and Calmant, S.: Surface freshwater storage and dynamics in the Amazon basin during the 2005 exceptional drought, Environ. Res. Lett., 7, 044010, doi:10.1088/17489326/7/4/044010, 2012.

Fung, I., John, J., Lerner, J., Matthews, E., Prather, M., Steele, L., and Fraser, P.: Three-dimensional model synthesis of the global methane cycle, J. Geophys. Res., 96, 13033-13065, 1991.

Gauci, V., Blake, S., Stevenson, D. S., and Highwood, E. J.: Halving of the northern wetland $\mathrm{CH}_{4}$ source by a large Icelandic volcanic eruption, J. Geophys. Res., 113, G00A11, doi:10.1029/2007JG000499, 2008.

Gomez-Pelaez, A., Ramos, R., Cuevas, E., and Gomez-Trueba, V.: 25 years of continuous $\mathrm{CO}_{2}$ and $\mathrm{CH}_{4}$ measurements at Izaña Global GAW mountain station: annual cycles and interannual trends, in: Proceedings of the Symposium on Atmospheric Chemistry and Physics at Mountain Sites (ACP Symposium 2010), 157-159, Interlaken, Switzerland, 2010.

Guimberteau, M., Drapeau, G., Ronchail, J., Sultan, B., Polcher, J., Martinez, J.-M., Prigent, C., Guyot, J.-L., Cochonneau, G., Espinoza, J. C., Filizola, N., Fraizy, P., Lavado, W., De Oliveira,
E., Pombosa, R., Noriega, L., and Vauchel, P.: Discharge simulation in the sub-basins of the Amazon using ORCHIDEE forced by new datasets, Hydrol. Earth Syst. Sci., 16, 911-935, doi:10.5194/hess-16-911-2012, 2012.

Hauglustaine, D., Hourdin, F., Jourdain, L., Filiberti, M., Walters, S., Lamarque, J., and Holland, E.: Interactive chemistry in the Laboratoire de Météorologie Dynamique general circulation model: Description and background tropospheric chemistry evaluation, J. Geophys. Res., 109, D04314, doi:10.1029/2003JD003957, 2004.

Heimann, M. and Marshall, J.: $\mathrm{CH}_{4}$ Flux Inversion Studies for $\mathrm{Fu}-$ ture Active Space $\mathrm{CH}_{4}$ Missions like MERLIN, AGU Fall Meeting Abstracts, p. C6, 2011.

Hess, L. L., Melack, J. M., Novo, E. M., Barbosa, C. C., and Gastil, M.: Dual-season mapping of wetland inundation and vegetation for the central Amazon basin, Remote Sens. Environ., 87, 404428, 2003.

Hodson, E. L., Poulter, B., Zimmermann, N. E., Prigent, C., and Kaplan, J. O.: The El Niño-Southern Oscillation and wetland methane interannual variability, Geophys. Res. Lett., 38, L08810, doi:10.1029/2011GL046861, 2011.

Hogan, K. B. and Harriss, R. C.: Comment on "A dramatic decrease in the growth rate of atmospheric methane in the Northern Hemisphere during 1992" by E. J. Dlugokencky et al., Geophys. Res. Lett., 21, 2445-2446, 1994.

Hourdin, F., Musat, I., Bony, S., Braconnot, P., Codron, F., Dufresne, J.-L., Fairhead, L., Filiberti, M.-A., Friedlingstein, P., Grandpeix, J.-Y., Krinner, G., LeVan, P., Li, Z.-X., and Lott, F.: The LMDZ4 general circulation model: climate performance and sensitivity to parametrized physics with emphasis on tropical convection, Clim. Dynam., 27, 787-813, 2006.

Kai, F. M., Tyler, S. C., Randerson, J. T., and Blake, D. R.: Reduced methane growth rate explained by decreased Northern Hemisphere microbial sources, Nature, 476, 194-197, 2011.

Kaminski, T., Rayner, P. J., Heimann, M., and Enting, I. G.: On aggreation errors in atmospheric transport inversions, J. Geophys Res., 106, 4703-4715, doi:10.1029/2000JD900581, 2001.

Kaplan, J. O.: Wetlands at the Last Glacial Maximum: Distribution and methane emissions, Geophys. Res. Lett., 29, 3-1-3-4, 2002.

Kirschke, S., Bousquet, P., Ciais, P., Saunois, M., Canadell, J. G., Dlugokencky, E. J., Bergamaschi, P., Bergmann, D., Blake, D. R., Bruhwiler, L., Cameron-Smith, P., Castaldi, S., Chevallier, F., Feng, L., Fraser, A., Heimann, M., Hodson, E. L., Houweling, S., Josse, B., Fraser, P. J., Krummel, P. B., Lamarque, J.-F., Langenfelds, R. L., Le Quere, C., Naik, V., O’Doherty, S., Palmer, P. I., Pison, I., Plummer, D., Poulter, B., Prinn, R. G., Rigby, M., Ringeval, B., Santini, M., Schmidt, M., Shindell, D. T., Simpson, I. J., Spahni, R., Steele, L. P., Strode, S. A., Sudo, K., Szopa, S., van der Werf, G. R., Voulgarakis, A., van Weele, M., Weiss, R. F., Williams, J. E., and Zeng, G.: Three decades of global methane sources and sinks, Nature Geosci., 6, 813-823, doi:10.1038/ngeo1955, 2013.

Koven, C. D., Ringeval, B., Friedlingstein, P., Ciais, P., Cadule, P., Khvorostyanov, D., Krinner, G., and Tarnocai, C.: Permafrost carbon-climate feedbacks accelerate global warming, P. Natl. Acad. Sci., 108, 14769-14774, doi:10.1073/pnas.1103910108, 2011.

Krinner, G., Viovy, N., de Noblet-Ducoudré, N., Ogee, J., Polcher, J., Friedlingstein, P., Ciais, P., Sitch, S., and Prentice, I.: A 
dynamic global vegetation model for studies of the coupled atmosphere-biosphere system, Global Biogeochem. Cy., 19, GB1015, doi:10.1029/2003GB002199, 2005.

Lamarque, J.-F., Bond, T. C., Eyring, V., Granier, C., Heil, A., Klimont, Z., Lee, D., Liousse, C., Mieville, A., Owen, B., Schultz, M. G., Shindell, D., Smith, S. J., Stehfest, E., Van Aardenne, J., Cooper, O. R., Kainuma, M., Mahowald, N., McConnell, J. R., Naik, V., Riahi, K., and van Vuuren, D. P.: Historical (1850-2000) gridded anthropogenic and biomass burning emissions of reactive gases and aerosols: methodology and application, Atmos. Chem. Phys., 10, 7017-7039, doi:10.5194/acp10-7017-2010, 2010.

Langenfelds, R., Francey, R., Pak, B., Steele, L., Lloyd, J., Trudinger, $\mathrm{C}$., and Allison, C.: Interannual growth rate variations of atmospheric $\mathrm{CO}_{2}$ and its $\delta^{13} \mathrm{C}, \mathrm{H}_{2}, \mathrm{CH}_{4}$, and $\mathrm{CO}$ between 1992 and 1999 linked to biomass burning, Global Biogeochem. Cy., 16, 1048, doi:10.1029/2001GB001466, 2002.

Lawrence, D. M. and Slater, A. G.: Incorporating orgainc soil into a global climate model, Clim. Dynam., 30, 145-160, doi:10.1007/s00382-007-0278-1, 2007.

Levin, I., Veidt, C., Vaughn, B. H., Brailsford, G., Bromley, T., Lowe, R. H. D., Miller, J. B., Poß, C., and White, J. W. C.: No inter-hemispheric $\delta^{13} \mathrm{CH}_{4}$ trend observed, Nature, 486, E3-E4, doi:10.1038/nature11175, 2012.

Lowe, D., Brenninkmeijer, C., Tyler, S., and Dlugkencky, E.: Determination of the Isotopic Composition of Atmospheric Methane and its Application in the Antarctic, J. Geophys. Res., 96, 1545515467, 1991.

Matsueda, H., Sawa, Y., Wada, A., Inoue, H. Y., Suda, K., Hirano, Y., Tsuboi, K., and Nishioka, S.: Methane standard gases for atmospheric measurements at the MRI and JMA and intercomparison experiments, Papers in Meteorology and Geophysics, 54, 91-109, 2004.

Matthews, E. and Fung, I.: Methane emission from natural wetlands: Global distribution, area, and environmental characteristics of sources, Global Biogeochem. Cy., 1, 61-86, doi:10.1029/GB001i001p00061, 1987.

Melton, J. R., Wania, R., Hodson, E. L., Poulter, B., Ringeval, B., Spahni, R., Bohn, T., Avis, C. A., Beerling, D. J., Chen, G., Eliseev, A. V., Denisov, S. N., Hopcroft, P. O., Lettenmaier, D. P., Riley, W. J., Singarayer, J. S., Subin, Z. M., Tian, H., Zürcher, S., Brovkin, V., van Bodegom, P. M., Kleinen, T., Yu, Z. C., and Kaplan, J. O.: Present state of global wetland extent and wetland methane modelling: conclusions from a model intercomparison project (WETCHIMP), Biogeosciences, 10, 753788, doi:10.5194/bg-10-753-2013, 2013.

Miguez-Macho, G. and Fan, Y.: The role of groundwater in the Amazon water cycle: 1. Influence on seasonal streamflow, flooding and wetlands, J. Geophys. Res., 117, D15113, doi:10.1029/2012JD017539, 2012.

Miller, J., Gatti, L., d'Amelio, M., Crotwell, A., Dlugokencky, E., Bakwin, P., Artaxo, P., and Tans, P.: Airborne measurements indicate large methane emissions from the eastern Amazon basin, Geophys. Res. Lett., 34, L10809, doi:10.1029/2006GL029213, 2007.

Monteil, G., Houweling, S., Dlugockenky, E. J., Maenhout, G., Vaughn, B. H., White, J. W. C., and Rockmann, T.: Interpreting methane variations in the past two decades using measurements of $\mathrm{CH}_{4}$ mixing ratio and isotopic composition, Atmos. Chem. Phys., 11, 9141-9153, doi:10.5194/acp-11-9141-2011, 2011.

Montzka, S., Spivakovsky, C., Butler, J., Elkins, J., Lock, L., and Mondeel, D.: New Observational Constraints for Atmospheric Hydroxyl on Global and Hemispheric Scales, Science, 288, 500503, doi:10.1126/science.288.5465.500, 2000.

Montzka, S., Krol, M., Dlugokencky, E., Hall, B., Jöckel, P., and Lelieveld, J.: Small interannual variability of global atmospheric hydroxyl, Science, 331, 67-69, doi:10.1126/science.1197640, 2011.

Morino, I., Uchino, O., Inoue, M., Yoshida, Y., Yokota, T., Wennberg, P. O., Toon, G. C., Wunch, D., Roehl, C. M., Notholt, J., Warneke, T., Messerschmidt, J., Griffith, D. W. T., Deutscher, N. M., Sherlock, V., Connor, B., Robinson, J., Sussmann, R., and Rettinger, M.: Preliminary validation of column-averaged volume mixing ratios of carbon dioxide and methane retrieved from GOSAT short-wavelength infrared spectra, Atmos. Meas. Tech., 4, 1061-1076, doi:10.5194/amt-4-1061-2011, 2011.

NOAA: NOAA data website, http://www.esrl.noaa.gov/gmd/dv/ ftpdata.html, last access: March 2012.

Olivier, J. G. J. and Berdowski, J. J. M.: The Climate System, chap. Global emissions sources and sinks, 33-37, A. A. Balkema/Swets \& Zeitlinger, J. Berdowski, R. Guichert, B. Heij, 2001.

Papa, F., Prigent, C., Aires, F., Jimenz, C., Rossow, W., and Matthews, E.: Interannual variability of surface water extent at the global scale, 1993-2004, J. Geophys. Res., 115, D12111, doi:10.1029/2009JD012674, 2010.

Peylin, P., Bousquet, P., Ciais, P., and Monfray, P.: Differences of $\mathrm{CO}_{2}$ flux estimates based on a time-independent versus a timedependent inversion method, 295-309, American Geophysical Union, 2000.

Peylin, P., Baker, D., Sarmiento, J., Ciais, P., and Bousquet, P.: Influence of transport uncertainty on annual mean and seasonal inversions of atmospheric $\mathrm{CO}_{2}$ data, J. Geophys. Res.-Atmos., 107, 4385, doi:10.1029/2001JD000857, 2002.

Pison, I., Bousquet, P., Chevallier, F., Szopa, S., and Hauglustaine, D.: Multi-species inversion of $\mathrm{CH}_{4}, \mathrm{CO}$ and $\mathrm{H}_{2}$ emissions from surface measurements, Atmos. Chem. Phys., 9, 5281-5297, doi:10.5194/acp-9-5281-2009, 2009.

Prigent, C., Papa, F., Aires, F., Jimenez, C., Rossow, W. B., and Matthews, E.: Changes in land surface water dynamics since the 1990 s and relation to population pressure, Geophys. Res. Lett., 39, L08403, doi:10.1029/2012GL051276, 2012.

Prinn, R., Weiss, R., Fraser, P., Simmonds, P. G., Cunnold, D., Alyea, F., O’Doherty, S., Salameh, P., Miller, B., Huang, J., Wang, R., Hartley, D., Harth, C., Steele, L., Sturrock, G., Midgley, P. M., and McCulloch, A.: A history of chemically and radiatively important gases in air deduced from ALE/GAGE/AGAGE, J. Geophys. Res., 115, 17751-17792, 2000.

Prinn, R., Huang, J., Weiss, R., Cunnold, D. M., Fraser, P., Simmonds, P., McCulloch, A., Harth, C., Reimann, S., Salameh, P., O’Doherty, S., Wang, R., Porter, L., Miller, B., and Krummel, P.: Evidence for variability of atmospheric hydroxyl radicals over the past quarter century, Geophys. Res. Lett., 32, L07809, doi:10.1029/2004GL022228, 2005.

Prinn, R. G., Weiss, R. F., Fraser, P. J., Simmonds, P. G., Cunnold, D. M., O'Doherty, S., Salameh, P. K., Porter, L. W., Krummel, P. B., Wang, R. H. J., Miller, B. R., Harth, C., Greally, B. R., Woy, 
F. A. V., Steele, L. P., Mühle, J., Sturrock, G. A., Alyea, F. N., Huang, J., and Hartley, D. E.: AGAGE data base, Tech. rep., The ALE/GAGE/AGAGE Network, http://agage.eas.gatech.edu/ index.htm, last access: March 2012.

Rigby, M., Prinn, R., Fraser, P., Simmonds, P., Langenfelds, R., Huang, J., Cunnold, D., Steele, L., Krummel, P., Weiss, R., O'Doherty, S., Salameh, P., Wang, H., Harth, C., Mülhe, J., and Porter, L.: Renewed growth of atmospheric methane, Geophys. Res. Lett, 35, L22805, doi:10.1029/2008GL036037, 2008.

Ringeval, B., de Noblet-Ducoudré, N., Ciais, P., Bousquet, P., Prigent, C., Papa, F., and Rossow, W.: An attempt to quantify the impact of changes in wetland extention methane emissions at the seasonal and interannual time scales, Global Biogeochem. Cy., GB2003, 24, doi:10.1029/2008GB003354, 2010.

Ringeval, B., Friedlingstein, P., Koven, C., Ciais, P., de NobletDucoudré, N., Decharme, B., and Cadule, P.: Climate- $\mathrm{CH}_{4}$ feedback from wetlands and its interaction with the climate$\mathrm{CO}_{2}$ feedback, Biogeosciences, 8, 2137-2157, doi:10.5194/bg8-2137-2011, 2011.

Ringeval, B., Decharme, B., Piao, S. L., Ciais, P., Papa, F., de Noblet-Ducoudré, N., Prigent, C., Friedlingstein, P., Gouttevin, I., Koven, C., and Ducharne, A.: Modelling sub-grid wetland in the ORCHIDEE global land surface model: evaluation against river discharges and remotely sensed data, Geosci. Model Dev., 5, 941-962, doi:10.5194/gmd-5-941-2012, 2012.

Ringeval, B., Hopcroft, P. O., Valdes, P. J., Ciais, P., Ramstein, G., Dolman, A. J., and Kageyama, M.: Response of methane emissions from wetlands to the Last Glacial Maximum and an idealized Dansgaard-Oeschger climate event: insights from two models of different complexity, Clim. Past, 9, 149-171, doi:10.5194/cp-9-149-2013, 2013.

Schmidt, M., Ramonet, M., Wastine, B., Delmotte, M., Galdemard, P., Kazan, V., Messager, C., Royer, A., Valant, C., Xueref, I., and Ciais, P.: RAMCES: The French Network of Atmospheric Greenhouse Gas Monitoring, in: 13th WMO/IAEA Meeting of Experts on Carbon Dioxide Concentration and Related Tracers Measurement Techniques, GAW report No. 168 (2006), 165174, Boulder, Colorado, USA, 2005.

Simpson, I. J., Andersen, M. P. S., Meinardi, S., Bruhwiler, L., Blake, N. J., Helmig, D., Rowland, F. S., and Blake, D. R.: Long-term decline of global atmospheric ethane concentrations and implications for methane, Nature, 488, 490-494, doi:10.1038/nature11342, 2012.

Sussmann, R., Forster, F., Rettinger, M., and Bousquet, P.: Renewed methane increase for five years (2007-2011) observed by solar FTIR spectrometry, Atmos. Chem. Phys., 12, 4885-4891, doi:10.5194/acp-12-4885-2012, 2012.

UBA: UBA website, http://www.umweltbundesamt.de/luft/ luftmessnetze/ubamessnetz.htm, 2012.

Uppala, S. M., Kållberg, P. W., Simmons, A. J., Andrae, U., Bechtold, V. D. C., Fiorino, M., Gibson, J. K., Haseler, J., Hernandez, A., Kelly, G. A., Li, X., Onogi, K., Saarinen, S., Sokka, N., Allan, R. P., Andersson, E., Arpe, K., Balmaseda, M. A., Beljaars, A. C. M., Berg, L. V. D., Bidlot, J., Bormann, N., Caires, S., Chevallier, F., Dethof, A., Dragosavac, M., Fisher, M., Fuentes, M., Hagemann, S., Hólm, E., Hoskins, B. J., Isaksen, L., Janssen, P. A. E. M., Jenne, R., Mcnally, A. P., Mahfouf, J.-F., Morcrette, J.-J., Rayner, N. A., Saunders, R. W., Simon, P., Sterl, A., Trenberth, K. E., Untch, A., Vasiljevic, D., Viterbo, P., and
Woollen, J.: The ERA-40 re-analysis, Q. J. Roy. Meteorol. Soc., 131, 2961-3012, doi:10.1256/qj.04.176, 2005.

van der Werf, G. R., Randerson, J. T., Collatz, G. J., Giglio, L., Kasibhatla, P. S., Arellano, A. F., Olsen, S. C., and Kasischke, E. S.: Continental-Scale Partitioning of Fire Emissions During the 1997 to 2001 El Niño/La Niña Period, Science, 303, 73-76, doi:10.1126/science.1090753, 2004.

van der Werf, G. R., Randerson, J. T., Giglio, L., Collatz, G. J., Kasibhatla, P. S., and Arellano Jr., A. F.: Interannual variability in global biomass burning emissions from 1997 to 2004, Atmos. Chem. Phys., 6, 3423-3441, doi:10.5194/acp-6-3423-2006, 2006.

van der Werf, G. R., Randerson, J. T., Giglio, L., Collatz, G. J., Mu, M., Kasibhatla, P. S., Morton, D. C., DeFries, R. S., Jin, Y., and van Leeuwen, T. T.: Global fire emissions and the contribution of deforestation, savanna, forest, agricultural, and peat fires (19972009), Atmos. Chem. Phys., 10, 11707-11735, doi:10.5194/acp10-11707-2010, 2010.

Viovy, N. and Ciais, P.: A combined dataset for ecosystem modelling, available at: http://dods.extra.cea.fr/store/p529viov/ cruncep/V4_1901_2012/,2009.

Walter, B., Heimann, M., and Matthews, E.: Modeling modern methane emissions from natural wetlands 1 . Model description and results, J. Geophys. Res., 106, 34189-34206, 2001a.

Walter, B., Heimann, M., and Matthews, E.: Modeling modern methane emissions from natural wetlands 2 . Interannual variations 1982-1993, J. Geophys. Res., 106, 34207-34219, 2001b.

Wang, J., Logan, J., McElroy, M., Duncan, B., Megretskaia, I., and Yantosca, R.: A 3-D model analysis of the slowdown and interannual variability in the methane growth rate from 1988 to 1997, Global Biogeochem. Cy., 18, GB3011, doi:10.1029/2003GB002180, 2004.

Wania, R., Melton, J. R., Hodson, E. L., Poulter, B., Ringeval, B., Spahni, R., Bohn, T., Avis, C. A., Chen, G., Eliseev, A. V., Hopcroft, P. O., Riley, W. J., Subin, Z. M., Tian, H., van Bodegom, P. M., Kleinen, T., Yu, Z. C., Singarayer, J. S., Zürcher, S., Lettenmaier, D. P., Beerling, D. J., Denisov, S. N., Prigent, C., Papa, F., and Kaplan, J. O.: Present state of global wetland extent and wetland methane modelling: methodology of a model inter-comparison project (WETCHIMP), Geosci. Model Dev., 6, 617-641, doi:10.5194/gmd-6-617-2013, 2013.

White, J. R., Shannon, R. D., Weltzin, J. F., Pastor, J., and Bridgham, S. D.: Effects of soil warming and drying on methane cycling in a northern peatland mesocosm study, J. Geophys. Res., 113, G00A06, doi:10.1029/2007JG000609, 2008.

World Data Center for Greenhouse Gases: WDCGG website, http: //ds.data.jma.go.jp/gmd/wdcgg/, last access: April 2012.

Worthy, D., Levin, I., Trivett, N., Kuhlmann, A., Hopper, J., and Ernst, M.: Seven years of continuous methane observations at a remote boreal site in Ontario, Canada, J. Geophys. Res., 103, 15995-16007, doi:10.1029/98JD00925, 1998. 